\title{
Planning and pandemics COVID 19 illuminates why urban planners should have listened to food advocates all along
}

\author{
Samina Raja ${ }^{1}$ \\ Accepted: 25 April 2020 / Published online: 11 May 2020 \\ (c) Springer Nature B.V. 2020
}

Keywords Food systems planning $\cdot$ Food policy $\cdot$ Food equity $\cdot$ Local government policy $\cdot$ COVID-19 $\cdot$ Coronavirus

Our communities' food systems-all the structures, resources, and policies that enable food to travel from farm to plate- have been frayed for a long time. Black and brown neighborhoods in cities are redlined by supermarkets. Low nutrient, hyper processed foods are readily and cheaply available while high nutrition foods are hard to come by. Consolidation in the food industry has shortchanged farmers and consumers. Wages and benefits for workers-farmworkers, restaurant workers, grocery store workers-who are responsible for harvesting, packing, processing, shelving food have long been ignored. These problems are not new. Community advocates have been drawing our attention to structural disparities in our food systems for a long time. Our policy makers just didn't listen.

COVID-19 has both exacerbated and illuminated the fractures in our food system. I am especially concerned about the ways in which local, regional, and metropolitan governments are prepared to respond. Nearly 40,000 local, regional, and metropolitan (LRM) governments in the United States are charged with providing services that make our counties, cities, towns, and villages inhabitable. LRM governments provide a host of services ranging from roads, sewers, to waste management, etc. They also plan for the future of their communities, shepherding public funding to guide future land use, economic development, public transportation, housing, etc. Concern for a community's food infrastructure was not, and is not part of LRM services and/or plans. A 2014 national survey of members of the American Planning Association (APA) who worked for local governments reported

This article is part of the Topical Collection: Agriculture, Food \& Covid-19.

Samina Raja

sraja@buffalo.edu

1 University at Buffalo, Buffalo, USA that only $1 \%$ of their local governments view food systems as a priority. One percent. In other words, food is not viewed as a public concern by LRM governments.

Yet, in the wake of the COVID 19 pandemic, food-related work has suddenly been redefined as 'essential,' as if there was any time when people did not eat. Workers up and down the food supply chain are now being heralded as 'frontline' workers. The hypocrisy of our governments, federal, state, and local, is both absurd and galling.

Community coalitions are stepping up where policy leaders are falling short. In Buffalo, New York. A coalition of nearly 80 individuals and organizations is coordinating an acute and long-term response to COVID. The Seeding Resilience coalition, which includes growers, emergency food providers, bicycle couriers, food system planners, food justice advocates, researchers, and others, rapidly developed a three-pronged strategy to respond to COVID. Seeding Resilience aims to (1) rapidly redistribute food to neighborhoods in need; (2) increase food production in the city; and (3) increase employment opportunities. To address the acute crisis, food is being procured from local and/or minorityowned wholesalers and/or farmers. Food is being distributed by Feed Buffalo, an emergency food pantry that intentionally serves healthy and halal food with dignity. Food is being transported by bicycle couriers and volunteer drivers to anyone who requests it, while offering vegan, organic, and halal food. For a more equitable recovery, the coalition is increasing food production city-wide through a network of backyard/frontyard Freedom Gardens, a term coined by Gail Wells, a longtime food justice advocate. Led by a partnership of Food for the Spirit, an emerging organization committed to cultivating spaces for racial healing, ecological justice, and equitable food systems, and Grassroots Gardens of Western New York, a not-for profit organization that supports community gardens, the new Freedom Gardens both respond to the present crisis and seed a more equitable future 
by giving city residents greater control over their own means of food production. Seeding Resilience's rapid yet deliberate response is made possible due to pre-existing networks in the community, such as the Buffalo Food Equity Network (BFEN), a movement of Black, Indigenous, and People of Color (BIPOC).

If we are to aim for more equitable post-COVID food systems, local, regional, and metropolitan governments across the United States will have to address the deep structural problems in their communities' food systems. They must support efforts like Seeding Resilience in Buffalo. For starters, they will need to remember that food systems are an essential and public infrastructure. Working with their state governments, LRM governments will have to reinvest in their communities' food systems, especially if the federal government continues to abdicate its responsibilities. They will have to dedicate capital and operating budgets in their communities' food systems. Fortunately, we have examples of how this has been done by a small number of innovative local governments, as highlighted by the national Growing Food Connections project. GFC offers a searchable database of how local governments are strengthening their food systems, along with $30+$ case studies of innovations. Cities of Baltimore, New York, and Seattle, for example, have been planning and implementing policies to strengthen their food system. Holly Freishtat, Food Policy Director for city of Baltimore reflects on how their prior work in food system may have prepared them for COVID 19. Freishtat notes that "The Baltimore Food Policy Initiative created an Emergency Food Working Group and emergency food response plans, hired a Food Resilience Planner, and in collaboration with Johns Hopkins Center for a Livable Future, published a Food System Resilience Advisory Report and has conducted extensive food environment mapping. As a result, Baltimore City has been able to deploy certain strategies-such as federally-funded meals for children and seniors - to meet immediate needs while we worked to establish longer-term strategies that would be more appropriate for the realities of this pandemic." Municipal governments that were already engaged in strengthening their food systems are likely better positioned to respond to COVID 19 than those for whom food was not on the public policy radar.

If you are a policy leader or a planner wondering what an appropriate next step might be for your community's food system, reach out to community food advocates within your jurisdiction. And, remember, food systems are a public infrastructure, just as much as sidewalks.

\section{References}

Raja, Samina, Jill K. Clark, Julia Freedgood, and Kimberley Hodgson. 2018. Reflexive and inclusive: Reimagining local government engagement in food systems: Special Issue on Local Government in Food Systems Work. Journal of Agriculture, Food Systems, and Community Development 8 (Suppl. 2): 1-10.

Raja, Samina, and Jennifer Whittaker. 2018. Community Food Infrastructure: A Vital Consideration for Planning Healthy Communities. In Healthy Environments, Healing Spaces: Current Practices and Future Directions in Health, City Planning, and Design, ed. Timothy Beatley, Reuben Rainey, and Carla Jones. Charlottesville: University of Virginia Press.

Raja, Samina, Kevin Morgan, and Enjoli Hall. 2017. Planning for Equitable Urban and Regional Food Systems. Editorial. Special Issue on Planning for Equitable Urban and Regional Food Systems. Built Environment 43 (3): 309-314.

Publisher's Note Springer Nature remains neutral with regard to jurisdictional claims in published maps and institutional affiliations.

Samina Raja is the Associate Dean for Reseach and Inclusive Excellence at the School of Architecture and Planning at the University at Buffalo. She is the founder and Principal Investigator of the Food Systems Planning and Healthy Communities Lab (UB Food Lab). Her research, teaching, and civic service focuses on the role of peoplegenerated policy in building equitale, healthy, and sutsainable food systems and communities. 